\title{
First Record of Ostracods from the Upper Silurian Tambolar Formation, Argentine Precordillera
}

\author{
Author(s): María José Salas, Ana Mestre, María José Gómez and Yanina Garcias \\ Source: Ameghiniana, 55(3):253-262. \\ Published By: Asociación Paleontológica Argentina \\ URL: http://www.bioone.org/doi/full/10.5710/AMGH.23.04.2018.3140
}

BioOne (www.bioone.org) is a nonprofit, online aggregation of core research in the biological, ecological, and environmental sciences. BioOne provides a sustainable online platform for over 170 journals and books published by nonprofit societies, associations, museums, institutions, and presses.

Your use of this PDF, the BioOne Web site, and all posted and associated content indicates your acceptance of BioOne's Terms of Use, available at www.bioone.org/page/terms of use.

Usage of BioOne content is strictly limited to personal, educational, and non-commercial use.

Commercial inquiries or rights and permissions requests should be directed to the individual publisher as copyright holder. 

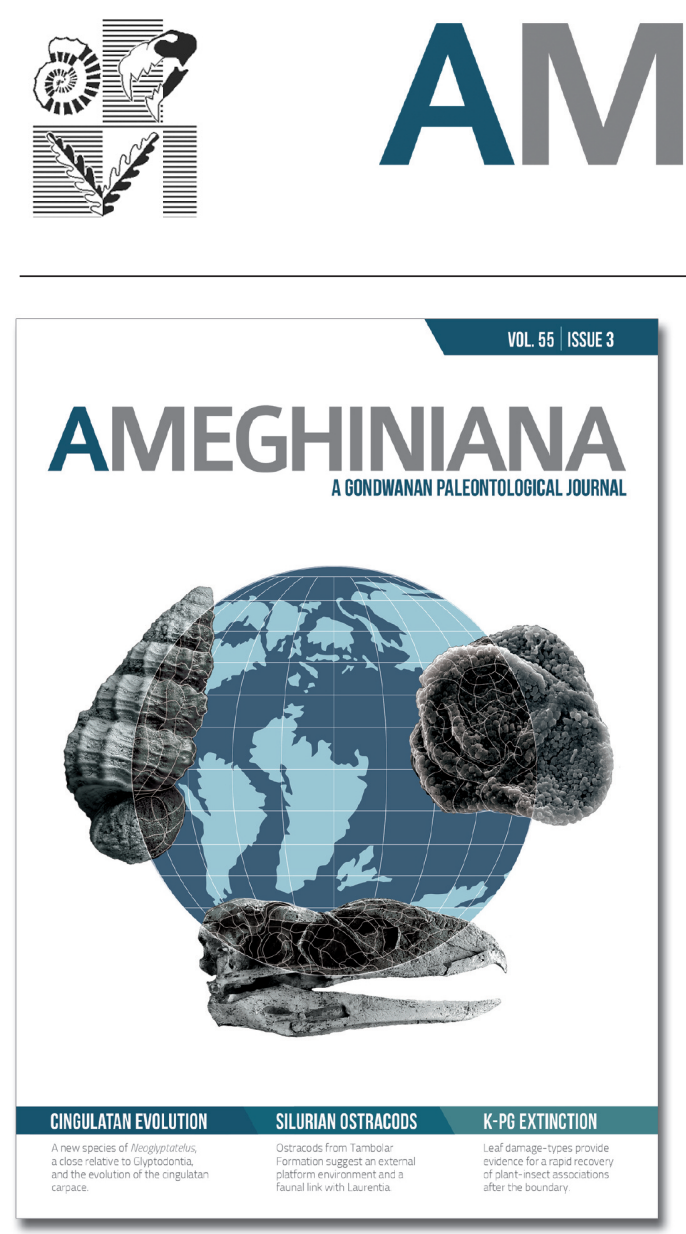

\title{
FIRST RECORD OF OSTRACODS FROM THE UPPER SILURIAN TAMBOLAR FORMATION, ARGENTINE PRECORDILLERA
}

\author{
MARÍA JOSÉ SALAS ${ }^{1}$ \\ ANA MESTRE ${ }^{2}$ \\ MARÍA JOSÉ GÓMEZ² \\ YANINA GARCIAS ${ }^{2}$
}

\begin{abstract}
${ }^{1}$ Centro de Investigaciones en Ciencias de la Tierra (Consejo Nacional de Investigaciones Científicas y Técnicas-Universidad Nacional de Córdoba) y Centro de Investigaciones Paleobiológicas (Universidad Nacional de Córdoba), Av. Vélez Sarsfield 1611, X5016GCA Córdoba, Argentina.

${ }^{2}$ Consejo Nacional de Investigaciones Científicas y Técnicas - Centro de Investigaciones de la Geósfera y la Biósfera (CIGEOBIO) - Instituto de Investigaciones Mineras, Facultad de Ingeniería, Universidad Nacional de San Juan, Libertador San Martín 1109, J5400ARL San Juan, Argentina.
\end{abstract}

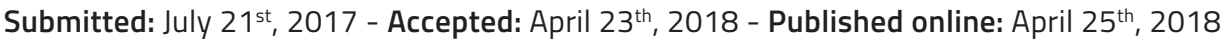

To cite this article: María José Salas, Ana Mestre, María José Gómez, and Yanina Garcias (2018). First record of ostracods from the upper Silurian Tambolar Formation, Argentine Precordillera. Ameghiniana 55: 253-262.

To link to this article: http://dx.doi.org/10.5710/AMGH.23.04.2018.3140

PLEASE SCROLL DOWN FOR ARTICLE

Also appearing in this issue:

\section{CINGULATAN EVOLUTION}

A new species of Neoglyptatelus, a close relative to Glyptodontia, and the evolution of the cingulatan carpace.

\section{SILURIAN OSTRACODS}

Ostracods from Tambolar

Formation suggest an external platform environment and a

faunal link with Laurentia.

\section{K-PG EXTINCTION}

Leaf damage-types provide evidence for a rapid recovery of plant-insect associations after the boundary. 


\title{
FIRST RECORD OF OSTRACODS FROM THE UPPER SILURIAN TAMBOLAR FORMATION, ARGENTINE PRECORDILLERA
}

\author{
MARÍA JOSÉ SALAS', ANA MESTRE², MARÍA JOSÉ GÓMEZ², AND YANINA GARCIAS²
}

${ }^{1}$ Centro de Investigaciones en Ciencias de la Tierra (Consejo Nacional de Investigaciones Científicas y Técnicas-Universidad Nacional de Córdoba) y Centro de Investigaciones Paleobiológicas (Universidad Nacional de Córdoba), Av. Vélez Sarsfield 1611, X5016GCA Córdoba, Argentina. mjsalas@unc.edu.ar ${ }^{2}$ Consejo Nacional de Investigaciones Científicas y Técnicas - Centro de Investigaciones de la Geósfera y la Biósfera (CIGEOBIO) - Instituto de Investigaciones Mineras, Facultad de Ingeniería, Universidad Nacional de San Juan, Libertador San Martín 1109, J5400ARL San Juan, Argentina. amestre@unsj.edu.ar; mjgomez@unsj.edu.ar, garcias.yanina@gmail.com

\begin{abstract}
Ostracods have been recovered from the upper levels of the Pachaco Facies of the Tambolar Formation of the Argentine Precordillera. Four species, two of which are new (Bollia sp. nov., Neothlipsura khiska sp. nov.), are described. An evaluation of the conodont fauna suggests an late Silurian (Pridoli) to possibly Early Devonian (earliest Lochkovian) age for the unit. The ostracod fauna is characterized by the absence of dimorphic Palaeocopina, forms typically abundant during the Silurian, and by the presence of Tricornina, a thin shelled spinose genus, together with representatives of Binodicopina and Metacopina (Thlipsuroidea). The taxonomic composition of the ostracods corresponds to the Assemblage III of the Eifelian Mega-Assemblage or to a "mixed assemblage", suggesting a deep subtidal environment close to the area of the storm wave base. This interpretation is consistent with an external platform environment proposed by other authors based on a stratigraphic analysis. The presence of ostracod taxa such as Neothlipsura khiska sp. nov. and Tricornina? sp. suggests a faunal link with the palaeocontinent of Laurentia.
\end{abstract}

Key words. Ostracods. Silurian. Taxonomy. Paleogeography. Argentina.

Resumen. PRIMER REGISTRO DE OSTRÁCODOS DEL SILÚRICO SUPERIOR DE LA FORMACIÓN TAMBOLAR, PRECORDILLERA ARGENTINA. Fueron estudiados los ostrácodos de los niveles superiores de la Facies Pachaco (Formación Tambolar) en la Precordillera Argentina. Se describieron cuatro especies, de las cuales dos son nuevas (Bollia sp. nov., Neothlipsura khiska sp. nov.). Una nueva evaluación de la fauna de conodontes registrada en la unidad sugiere una edad Silúrico tardío (Pridoliano)-?Devónico Temprano (Lochkoviano temprano) para la misma. La asociación de ostrácodos estudiada se destaca por la ausencia de Palaeocopina dimórficos, formas muy comunes durante el Silúrico y por la presencia de Tricornina, género de conchilla delgada y espinas, junto a Binodicopina y Metacopina (Thlipsuraceas). La composición taxonómica correspondería a la Asociación III de la Eifelian Mega Assemblage o "asociación de mezcla", hecho que sugiere un ambiente de plataforma cercano a la línea de base de olas de tormenta. Esta interpretación es consistente con el ambiente de plataforma externa propuesto por otros autores a partir del análisis estratigráfico de la unidad. Respecto a las afinidades paleobiogeográficas el material estudiado sugiere relaciones faunísticas con Laurentia, debido a la presencia de Neothlipsura khiska sp. nov. y Tricornina? sp.

Palabras clave. Ostrácodos. Silúrico. Taxonomía. Paleogeografía. Argentina.

THE ostracod fauna of the Silurian of Argentina has been scarcely documented. Hitherto studies of ostracods from Argentina have focused mainly on Ordovician (Schallreuter, 1996; Salas, 2002a, b, 2003, 2007, 2011; Salas et al., 2007; Salas and Vaccari, 2012) and Devonian faunas (Salas et al., 2013; Salas, 2016).

Thomas (1905) was the first to study Silurian ostracods from Argentina, with a brief description of the species Beyrichia argentina Thomas, 1905 which was probably recovered from the upper levels of the Los Espejos Formation. More recently, Vannier et al. (1995) described five ostracod species in an analysis of upper Silurian-Lower Devonian faunas from the Argentine Precordillera and the Bolivian Altiplano (Tarabuco and Santa Rosa formations). The precordilleran association that they described was collected from the upper part of the Los Espejos Formation at the Cerro del Fuerte section. This formation crops out extensively to the north of the San Juan River, encompassing most of the Central Precordillera. To the south, the Silurian deposits were classically named Tambolar Formation, the type locality for which is the Portezuelo del Tambolar section (Heim, 1952). Beresi (1980) extended this name to the Silurian deposits that overlie the San Juan Formation in the Pachaco area. Later, Peralta and León (1993) proposed the 
name "Pachaco Facies" of the Tambolar Formation for these deposits, due to the litological differences between these sediments and those of the type section.

In this pilot study we report new records of Silurian ostracods retrieved from the upper levels of the Tambolar Formation (Pachaco Facies), cropping out south of the San Juan River in the Pachaco locality. The material is abundant but the nature of its preservation prevents the identification of some of it. Palaeobiogeographical and palaeoenvironmental inferences will be made based on this material.

\section{GEOLOGICAL SETTING AND PROVENANCE OF THE MATERIAL}

The Tambolar Formation is exposed in the San Juan River area, Central Precordillera. The unit unconformably overlies the San Juan Formation, which consists of Ordovician limestones (Serpagli, 1974) and it is overlain in apparent paraconformity by the Lower Devonian shale of the Talacasto Formation. In its type section (Portezuelo de Tambolar) the Tambolar Formation is 60 m thick and comprises green and purple mudstones with green sandstone beds towards the top. The study area is located at the kilometer 91 of the National Road N²0 between the cities of San Juan and Calingasta. The Silurian outcrops of the area are named "Pachaco Facies" of the Tambolar Formation, and are exposed $1000 \mathrm{~m}$ west of the Pachaco locality. The succession is $23 \mathrm{~m}$ thick and composed of a lower and upper member, both of which have green and purple mudstones. The upper member exhibits two bioclastic levels in the upper part of the section (Fig. 1).

Previous works on the Tambolar Formation, carried out in the Guanaco Muerto section (southern end of the outcrops) can be mentioned. Peralta and León (1993) carried out a stratigraphical analysis of the unit and proposed a distal platform environment, close to the storm weather wave base, for the upper beds of this unit. The authors suggested a lithostratigraphic correlation of the Tambolar Formation (Pachaco Facies) with the La Chilca and Los Espejos formations, that crop out to the north of the Precordillera. In contrast, based in part on the presence of ripple marks on top of the beds and on the hydrodynamic reworking of the fossils, Franciosi (1995) interpreted a shallower environment for these deposits, proposing a possible internal platform affected by storms for the sequence. Regarding the age of the formation, Benedetto and Franciosi (1998) studied the brachiopod association recorded in the upper levels of the Pachaco Facies and suggested a Wenlock, Silurian age for these levels. The brachiopod association is composed of Orthostrophella n. sp. Benedetto and Franciosi, 1998, Dedzetina (Notodedzetina) silurica Benedetto in Benedetto et al. (1992), Leangella (Leangella) sp., Leptaena sp., Australina sp., Howellella? sp. and Harringtonina? sp. Mestre (2009) reported the first conodont record from the Tambolar Formation (Pachaco Facies) and proposed a Pridoli age for the unit.

The material that we studied comes from the northern part of the outcrop in La Horqueta Creek section, 1 km west of the Pachaco locality. The fauna was recovered from one fossiliferous horizon in the upper levels of the Pachaco Facies. The bed in question is 20 to $30 \mathrm{~cm}$ thick and consists of bioclastic sandstones with dispersed fragments of brachiopods and a high concentration of rugose corals and ostracods.

\section{MATERIAL AND METHODOLOGY}

The fossils studied were obtained by one of us (AM) when processing material to recover conodonts (Mestre, 2009). Approximately $4 \mathrm{~kg}$ of the bioclastic sandstone bed was dissolved in diluted formic acid using the techniques described by Stone (1987). The insoluble fraction of the sample was picked for ostracods and conodonts, resulting in the recovery of abundant ostracods and about 40 conodont elements. The ostracod valves are preserved as a replacement in silica and show a varied quality of preservation.

Institutional abbreviation. INGEO-MP, Instituto de GeologíaEmiliano Aparicio, Universidad Nacional de San Juan, San Juan, Argentina.

\section{CONODONT BIOSTRATIGRAPHY DISCUSSION}

Mestre (2009) carried out the first study of conodonts from the upper part of the Tambolar Formation (Pachaco Facies), which was suggested to be of early Pridoli, Silurian age. The assemblage is the first conodont fauna of that age to be recognized from the Precordillera and Argentina. It consists of Dapsilodus obliquicostatus (Branson and Mehl, 1933), Delotaxis cf. elegans (Walliser, 1964), Wurmiella cf. excavata (Branson and Mehl, 1933), Zieglerodina? cf. zellmeri Carls, Slavík and Valenzuela-Ríos, 2007 and Belodella sp. 

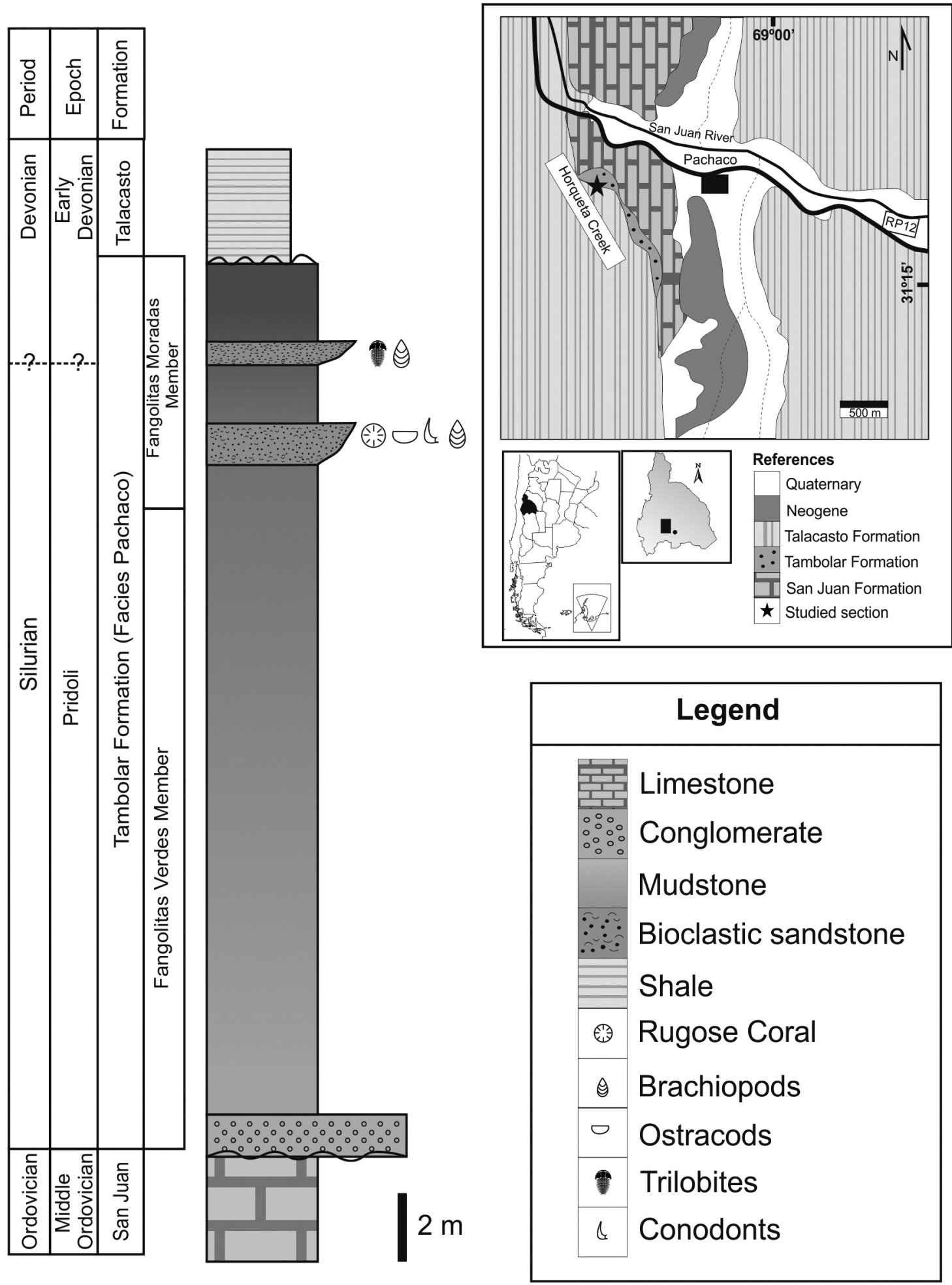

Figure 1. Map showing the geographical position of the fossiliferous site and a stratigraphical section of the Tambolar Formation (Pachaco Facies) indicating the ostracod-bearing levels. The black rectangle indicates Pachaco locality. 
Recently, knowledge of Silurian conodonts biostratigraphy of the Precordillera has increased with the studies of Gómez (2015), Garcías (2016), Gómez et al. (2017) and Mestre et al. (2017). Mindful of these advances, we undertook a taxonomic review of the conodont association recovered by Mestre (2009). The presence of Dapsilodus obliquicostatus, Wurmiella excavata, Oulodus elegans elegans, Zieglerodina sp. and Belodella sp. allows us to propose a new interpretation of the age of the upper part of the Tambolar Formation (Pachaco Facies).

The genus Zieglerodina Murphy, Valenzuela-Ríos and Carls, 2004 has its first appearance in the Pridoli, and reach its acme and higher diversification at the Silurian/Devonian boundary (Carls et al., 2007; Drygant and Szaniawski, 2012; Slavík et al., 2012; Gómez, 2015; Corriga et al., 2016; Corradini and Corriga, 2017; Huškova and Slavík, 2017). The conodont association and, especially, the presence of Zieglerodina, allows us to suggest a Pridoli-Lochkovian age for the upper part of the Tambolar Formation.

\section{SYSTEMATIC PALEONTOLOGY}

The taxonomic classification adopted herein follows that proposed by Mohibullah et al. (2014) and the references therein. The terms used for morphological features are based on Moore (1961) and Vannier et al. (1989). Abbreviations: Lmax, maximum length of the valve; Lmax:Hmax, maximum length/maximum height ratio; L1-L4, lobes from the anterior to posterior; N1, anterior node; N2, preadductorial node; S1-S2, sulci from anterior to posterior.

Order BEYRICHIOCOPIDA Pokorný, 1954

Suborder Palaeocopina Henningsmoen, 1953

Superfamily Drepanelloidea Ulrich and Bassler, 1923

Family BoLLIDAE Bouček, 1936

Genus Bollia Jones and Holl, 1886

Type species. Bollia uniflexa Jones and Holl, 1886, middle Silurian, England.

Bollia sp. nov.

Figure 2.1-3

Material. INGEO-MP 01, INGEO-MP 02, INGEO-MP 03,
INGEO-MP 04, INGEO-MP 12, INGEO-MP 13, INGEO-MP 14. Seven internal and external molds of left and right valves. Occurrence. The species is recorded from the upper levels of the Pachaco Facies in the Tambolar Formation, Pridolilower Lochkovian, in the La Horqueta Creek section, Pachaco area, Argentine Precordillera (Fig. 1).

Description. Subrectangular and amplete outline. Dorsal margin straight and long. Lmax reaching $1 \mathrm{~mm}$. Anterior and posterior outline slightly rounded, ventral margin slightly convex. The cardinal angles are well defined and obtuse, between $120^{\circ}$ and $130^{\circ}$. The valves bear two well developed, elevated lobes, which are straight, almost parallel, extend perpendicular from the dorsal margin to below valve mid-height, and are confluent below the adductorial sulcus by a prominent connecting lobe. L1 wider and higher than $L 2$, reaches the dorsal margin. S2 straight and narrow. Pseudovelum rounded, swollen, extends around the free margin, narrowed ventrally. A narrow furrow occurs around the lobate area. Marginal surface of the valve is wide and perpendicular to the lateral surface. Lateral surface smooth. Discussion. This material is clearly assigned to Bollia based on its lobal and adventral morphology. The material also shows affinity with Harpabollia Schallreuter, 1990 (Upper Ordovician of Baltoscandia, Bohemia, Carnic Alps and Argentina), mainly Harpabollia harparum (Troedsson, 1918) (in Schallreuter, 1990; Meidla, 1996, 2007) by its lobal features. However in Bollia sp. nov. L4 is clearly lacking and the adventral structure corresponds to the pseudovelum. The new species recalls Bollia bicollina Jones and Holl, 1886 (in Siveter, 2009) from the Silurian of England in its strong and rounded lobes. However in the new species the outline is more subrectangular, the adductorial sulcus S2 is narrower and longer. L1 is well developed and somewha swolen dorsally while in B. bicollina $\mathrm{L} 1$ is too narrow ventrally and bulb like dorsally. Respect to Bollia talacastensis Salas, 2016 from the Talacasto Formation (Lower Devonian), of San Juan, Argentina, the new species differs in its narrow extralobular surface and in its rounded pseudovelum, which is ridge like in the Devonian species. Compared with European and North African species all of them have a narrow extralobular surface and a rounded and well developed pseudovelum, however in Bollia lavibadia Becker, 1996 from the Lower Devonian of Spain the lobes are tilted to the anterior margin of valves and are bulb-like dorsally. Compared 
to Bollia bezagora Becker, 2004 (in Becker et al., 2004; Dojen, 2005; Dojen et al., 2007), from the Devonian of Spain, France and Morocco, the new species differs in the size of its lobes and in having a more pronounced pseudovelum. In addition in the new species the lobes and the adductorial sulcus are distinctly perpendicular to the dorsal margin while are tilted in B. bezagora. Bollia sp. nov. is similar to BoIlia azagora Becker, 2004 (in Becker et al., 2004; Dojen, 2005) in having different width of the lobes and in the rounded pseudovelum; however in the new species the lobes are wider, the extralobulate surface is a furrow and the outline of the valves is subrectangular. Bollia sp. nov. is also similar to Bollia sp. B sensu Zagora, 1968 (in Dojen et al., 2004) but the lobes are narrower. The formal erection of a new species is postponed because of the poor preservation and the scarcity of specimens.

Genus Ulrichia Jones, 1890

Type species. Ulrichia conradi Jones, 1890, Middle Devonian, United States of America.

\section{Ulrichia? sp.}

Figure 2.4-5

Material. One left, INGEO-MP 05 and one right valve, INGEO-MP 06.

Occurrence. The species is recorded from the upper levels of the Pachaco Facies in the Tambolar Formation, Pridoli?lower Lochkovian, in the La Horqueta section, Pachaco area, Argentine Precordillera (Fig. 1).

Description and discussion. This material recalls the genus Ulrichia in having two dorsal rounded nodes, a well-developed pseudovelum all around the free margin of the valves, an amplete outline and straight dorsal and ventral margins, anterior and posterior ends rounded, and a coarsely punctate lateral surface. However, as it is represented by only two poorly preserved valves this material is recorded in open nomenclature.

\section{Superfamily unknown}

Family TrICORNINIDAE Blumenstengel, 1965
Type species. Tricornina navicula Bouček, 1936, Silurian, Czech Republic.

\section{Tricornina? sp.}

Figure 2.6
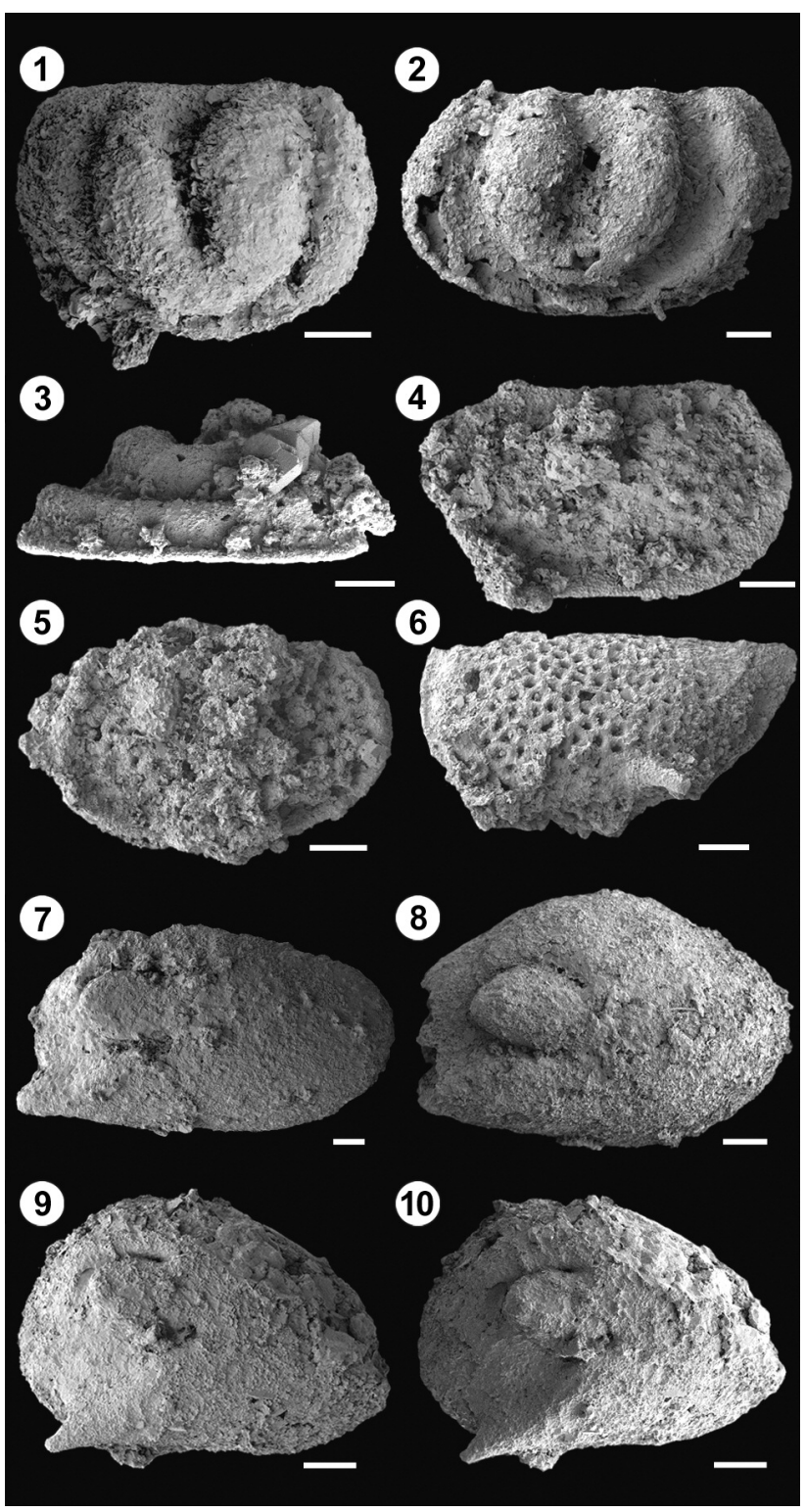

Figure 2. Ostracods from upper levels of Tambolar Formation (Pachaco Facies), Pridoli-?earliest Lochkovian, La Horqueta Creek section, Pachaco. 1-3, Bollia sp. nov.; 1, lateral view of right valve, INGEO-MP 02; 2 , lateral view of left valve, INGEO-MP 03; 3, ventral view of right valve, INGEO-MP 04. 4-5, Ulrichia? sp.; 4, lateral view of right valve, INGEO-MP 06; 5, lateral view of left valve, INGEO-MP 05. 6, Tricornina? sp., lateral view of left valve, INGEO-MP 07. 7-10, Neothlipsura khiska sp. nov.; 7, paratype, lateral view of right valve, INGEO-MP 09; 8, paratype, lateral view of right valve, INGEO-MP 11; 9-10, holotype, right valve, lateral and posterolateral views, INGEOMP 10. Scale bars $=100 \mu \mathrm{m}$. 
Material. INGEO-MP 07 and INGEO-MP 08. Two left valves. Occurrence. The species is recorded in the upper levels of the Pachaco Facies in the Tambolar Formation, Pridoli-?lower Lochkovian, in the La Horqueta section, Pachaco area, Argentine Precordillera (Fig. 1).

Description. The valves are preplete and have a triangular outline (Lmax=0.76 mm; Lmax:Hmax=1.9). The anterior outline is broadly rounded and the posterior one is gently rounded. The dorsal margin is straight and coincides with the maximum valve length. Cardinal angles well defined; the anterior one is obtuse and the posterior acute. Posteroventrally the valves bear a small, posteriorly directed spine. Anterior and posterior ends are slightly flattened. Lateral surface coarsely pitted.

Discussion. This form is known from only two poorly preserved specimens. The material resembles Tricornina in its triangular outline, the presence of a spine and the slightly flattened ends. The lack of a dorsal spine leaves the generic assignment in doubts (see Gründel, 1966; Stone and Berdan, 1984).

Order Podocopida Müller, 1894

Suborder Metacopina Sylvester-Bradley in Benson et al., 1961

Superfamily THLIPSUROIDEA Ulrich, 1894

Family THLIPSURIDAE Ulrich, 1894

Genus Neothlipsura Krandijevsky, 1968

Type species. Neothlipsura confluens (Swartz, 1932), posterior designation, from the Shriver Formation, Lower Devonian, of Pennsylvania.

\section{Neothlipsura khiska sp. nov.}

Figure $2.7-10$

Derivation of name. From quechua language "khiska" meaning spine.

Diagnosis. Neothlipsura species with a low outline, narrow posterior sulci, well developed medium lobe and ventral lobe extended into a spine.

Holotype. INGEO-MP 10, right valve, Lmax= 0.72 mm (Fig. 2.9-2.10).

Paratypes. INGEO-MP 09, right valve, Lmax= $1.08 \mathrm{~mm}$ (Fig. 2.7); INGEO-MP 11, right valve, Lmax=0.84 mm (Fig. 2.8). Type locality and age. Upper levels of the Pachaco Facies,
Tambolar Formation, Pridoli-?lower Lochkovian, in the La Horqueta Creek section, Pachaco area, Argentine PrecordiIlera (Fig. 1).

Material. INGEO-MP 15-INGEO-MP 27. Five left valves and eight right valves in addition to the illustrated material.

Occurrence. Only known from the type locality.

Description. Subovate, slightly postplete outline; small instars are more subcircular. Dorsal margin strongly curved to sub-triangular, anterior part slightly longer than the posterior part. Ventral margin almost straight. Anterior and posterior outline curved, anterior outline sharper than the posterior. Maximum length in the ventral half of the valve, Lmax reaches $1.13 \mathrm{~mm}$, Lmax:Hmax ca. 1.69. Carapace is convex overall, except in the posterior part of the valves, which is depressed. The depressed area extends anteriorly to valve mid-length as two deep, narrow furrows. The dorsal furrow is curved, the ventral furrow is straight. In lateral view the furrows separate three horizontal lobes that merge forward into the general surface of valves. The dorsal lobe is inconspicuous, like a continuation of the valve. The middle lobe is well developed with its posterior end rounded and prominent in the central posterior half of the valve. The ventral lobe is narrow, long and extended as a spine that overreaches the posterior outline of the valve. Lateral surfaces smooth.

Discussion. The genus Neothlipsura was established by Krandijevsky (1968), who included some North American species previously assigned to Thlipsura Jones and Holl, 1869. Lundin and Petersen (1975) reviewed species assigned to Thlipsura and Neothlipsura. In the material described herein diagnostic features such as the hinge and contact margin are unknown due to poor preservation. However, the valve outline and details of its lobation and sulcation justifies placement of the Argentinian material in Neothlipsura.

Neothlipsura khiska sp. nov. has features in common with Neothlipsura furca (Roth, 1929) from the Haragan Formation, Lower Devonian, of Oklahoma (Lundin, 1968). Both species have two straight furrows with three lobes. However, in the new species the outline of the adult valves is lower, the furrows are more incisive, the middle lobe is more developed than in N. furca and the ventral lobe is a spine. Neothlipsura jachalensis Vannier, Racheboeuf and Benedetto, 1995, a species also recorded from the Silurian of the Precordillera Argentina (Los Espejos Formation, Cerro 
del Fuerte section), differs in the position of the furrows, which are parallel in the new species and oblique in $N$. jachalensis; the middle lobe is rounded occupying all the surface between furrows. Both Neothlipsura robusta (Ulrich and Bassler, 1913) and Neothlipsura robusta var. tricornis (Swartz, 1932), from the Lower Devonian of Pennsylvania, have two straight sulci like those of the new species. However, in the North American forms, the sulci are short and the lobes are poorly developed. Other known congeneric species include Neothlipsura confluens, Neothlipsura furcoides (Bassler, 1941), Neothlipsura thyridioides (Swartz and Swain, 1941) and Neothlipsura whiteavesi (Copeland, 1962) from the Lower Devonian of the United States and Canada, and Neothlipsura primitiva (Roth, 1929) from the Silurian of the United States. Neothlipsura khiska differs from these taxa in having straight sulci and a less complicated pattern of sulci and lobes in the posterior half of the valve.

\section{GENERAL DISCUSSION}

The study of Silurian ostracods of Argentina, and in general throughout South America, is still in its infancy. Although the Silurian successions of Precordillera Argentina yield great numbers of fossils, ostracod faunas have attracted little attention until now. The present material from the Tambolar Formation in the Pachaco area, and the species described by Vannier et al. (1995) from the Los Espejos Formation, Cerro del Fuerte section, are the only Silurian species recorded so far. The material identified here is scarce and of low diversity, consisting of only four species. In addition, the species recorded by Vannier et al. (1995) are Hemsiella argentina (Thomas, 1905), Hemsiella helgae Vannier, Racheboeuf and Benedetto, 1995, Zorotoxis n. sp. Vannier, Racheboeuf and Benedetto, 1995, AustraIobollia fuertensis Vannier, Racheboeuf and Benedetto, 1995, Petrisigmoopsis sp., Neothlipsura jachalensis and Neothlipsura sp.; this makes for 10 species altogether. This diversity is relatively high considering that in other basins from Argentina and South America Silurian ostracods are virtually unknown. In addition to the Argentinian forms, Silurian ostracods have also been reported from Bolivia, Venezuela and Brazil. Přibyl (1984) described six species from different localities of Bolivia (Union, Cordillera Real and Catavi formations in the Cochabamba and La Paz departments); however, this fauna requires a modern taxonomic revision.
Vannier et al. (1995) considered at least four of the species described by Pribyl (1984) as indeterminate palaeocopes because of their poor preservation (only internal molds) and inadequate descriptions and illustrations. More recently, Hansch (1994) described two species of beyrichiacean palaeocopes from the Kirusillas Formation in the Bolivian Andes, as Hemsiella? n. sp. and an indeterminate palaeocope. Additionally, Martinsson (1964) reported the presence of Hemsiella andincola Martinsson, 1964 from the Silurian of Venezuela (Cordillera de Merida) and Clarke (1899) identified other two ostracods in Silurian deposits of Río Trombetas, Brazil. Clarke's material also needs taxonomic revision even though the affinities of Bollia lata var. brasiliensis Clarke, 1899 were recently discussed by several authors (Becker et al., 1994; Salas, 2016).

Compared to the fauna recorded from the Silurian section in Cerro del Fuerte (Los Espejos Formation) we point out the lack of dimorphic palaeocopes in our fauna; such forms are very common in the Silurian. In the Cerro del Fuerte locality the fauna is characterized by the abundance of the palaeocopes Hemsiella Martinsson, 1962 and Zorotoxotis Siveter, 1980 (Vannier et al., 1995). Palaeocopes were also recorded in Silurian levels of Bolivia (Přibyl, 1984; Hansch, 1994) and Hemsiella andincola is, until now, the only Silurian species recorded in Venezuela (Martinsson, 1964). Although the absence of dimorphic palaeocope groups may be due to a collection bias, a large quantity of specimens was collected and notably none correspond to a palaeocope. Another difference is the presence, in the Pachaco section, of a possible species of Tricornina. The remaining composition of the faunas is similar in both sections of PrecordiIlera, with binodicopes represented by Bollia and possibly Ulrichia? in the present fauna and by Australobollia Vannier, Racheboeuf and Benedetto, 1995 and Petrisigmoopsis Pinto and Purper, 1981 in the Cerro del Fuerte section. Metacopina (Thlipsuracea) are also represented in both sections by Neothlipsura, although the species recorded are different.

This report is preliminary and only a limited number of taxa are described. Nevertheless, the ostracods from the Pachaco Formation correspond in general taxonomic composition to 'Assemblage III' of the Eifelian Mega Assemblage of Casier (1987) or to a "mix assemblage" of Becker and Bless (1990) as described by Vannier et al. (1995) for the Los Espejos Formation, because of the absence of dimorphic 
palaeocopes and the presence of binodicopes and metacopes. The Assemblage III indicates a deep subtidal environment, deposits between the fair weather and maximum storm wave base (Casier, 1987). The observed taxonomic composition, mainly the presence of metacopes, together with the possible presence of Tricornina, a genus with a thin carapace and spines, would suggest the deeper sector of the assemblage (Cassier, 1987; Becker and Bless, 1990; Vannier et al., 1995). This interpretation is consistent with the environment of a possible internal platform affected by storms proposed by Franciosi (1995).

Regarding paleobiogeographical affinities, the studied material would suggest a faunal link with Laurentia (North American mid-continent sensu Siveter, 1989 or Appohimchi Province sensu Berdan, 1990): taxa such as Neothlipsura khiska sp. nov. and Tricornina? sp. indicate this relationship. Neothlipsura, recorded in the studied section and also in Los Espejos Formation (Vannier et al.,1995), is a common genus in the upper Silurian and mainly Lower Devonian of the United States (Oklahoma, Pennsylvania, Tennessee and West Virginia) and Canada (New Brunswick) (Lundin and Petersen, 1975 and references cited therein). Tricornina is hitherto recorded in the upper Silurian of North America and Thuringia (Gründel, 1966; Copeland, 1977; Hansch, 1993). On the other hand Bollia and Ulrichia are both geographically and temporally widespread genera. This relationship agrees with the proposal by Vannier et al. (1995), who suggested that the ostracod fauna of the Los Espejos Formation (Cerro del Fuerte section) showed faunal links at the generic and specific level between South America, Laurentia (Appohimchi Province sensu Berdan, 1990) and AvaloniaBaltica (Baltic-British Province sensu Berdan, 1990).

Because knowledge of the Silurian ostracod faunas from Argentina is still in a preliminary stage, further conclusions based on comparisons of ostracod assemblages among different sections and basins and their paleobiogeographical affinities should be treated cautiously.

\section{ACKNOWLEDGEMENTS}

The authors thank the reviewers D. Siveter (University of Leicester, United Kingdom) and T. Meidla (University of Tartu, Estonia) for his constructive reviews of the manuscript and for their many helpful comments. We also thank S. Heredia for their comments and suggestions on the early version of the manuscript and field work assistance. We acknowledge the Centro de Investigaciones en Ciencias de la Tierra (CICTERRA), Consejo Nacional de Investigaciones Cien- tíficas y Técnicas-Universidad Nacional de Córdoba for providing logistical facilities. Financial support for this study was provided by Consejo Nacional de Investigaciones Científicas y Técnicas (CONICET) Grant PIP 2014-2016-0058CO. This is a contribution to PUE 2016 (CICTERRA - CONICET).

\section{REFERENCES}

Bassler, R.S. 1941. Ostracoda from the Devonian (Onondaga) chert of western Tennessee. Washington Academy of Science, Journal 31: 21-27.

Becker, G. 1996. Benthische Ostracoden aus dem Unterdevon des Palentinischen Beckens (Gedinnium - Unteremsium; Kantabrisches Gebirge, N-Spanien). Senckenbergiana lethaea 76: 133-157.

Becker, G., and Bless, M. 1990. Biotope indicative features in Palaeozoic ostracods: a global phenomenon. In: R. Watley, and C. Maybury (Eds.), Ostracoda and Global Events. British Micropalaeontological Society Publication Series. Chapman and Hall, London, p. 421-436.

Becker, G., Bless, M., and Theron, J. 1994. Malvinokaffric ostracods from South Africa (Southern Cape; Bokkeveld Group, Devonian). Courier Forschunginstitut Senckenberg 169: 239-259.

Becker, G., Lazreq, N., and Weddige, K. 2004. Ostracods of Thuringian provenance from the Devonian of Morocco. Palaeontographica Series A 271: 1-109.

Benedetto, J.L., Racheboeuf, P.R., Herrera, Z.A., Brussa, E., and Toro, B.A. 1992. Brachiopodes et biostratigraphie de la Formation Los Espejos, Silurien-Eodévonien de la Précordillère Argentine. Geobios 25: 599-637.

Benedetto, J.L., and Franciosi, M. 1998. Braquiópodos silúricos de las formaciones Tambolar y Rinconada en la Precordillera de San Juan, Argentina. Ameghiniana 35: 115-132.

Benson, R.H., Berdan, J.M., van den Bold, W.A., Hanai, T., Hessland, I., Howe, H.V., Kesling, R.V., Levinson, S.A., Reyment, R.A., Moore, R.C., Scott, H.W., Shaver, R.H., Sohn, I.G., Stover, L.E., Swain, F.M., and Sylvester-Bradley, P.C. 1961. Systematic description. In: R.C. Moore, and C.W. Pitrat (Eds.), Treatise on Invertebrate Paleontology, Part Q Arthropoda 3 Crustacea Ostracoda. Geological Society of America, Boulder and University of Kansas Press, Lawrence, p. Q99-Q421.

Berdan, J.M. 1990. The Silurian and Early Devonian biogeography of ostracodes in North America. In: W.S. McKerrow, and C.R. Scotese (Eds.), Palaeozoic Palaeogeography and Biogeography. Memoir 12. Geological Society, London, p. 223-231.

Beresi, M. 1980. El Paleozoico inferior en el tramo medio del río San Juan (Pachaco), Provincia de San Juan. Revista de la Asociación Geológica Argentina 35: 18-25.

Blumenstengel, H. 1965. Zur Ostracoden fauna eines Kalkgerölls aus dem Thüringer Lederschiefer (Ordovizium). Freiberger Forschungshefte C182: 63-76.

Bouček, B. 1936. Die ostracoden des Böhmischen Ludlows (Stufe). Neues Jahrbuch für Mineralogie, Geologie und Paläontologie 76: 31-98.

Branson, E.B., and Mehl, M.G. 1933. Conodonts from the Bainbridge (Silurian) of Missouri. University of Missouri Studies 8: 39-53.

Casier, J.G. 1987. Etude biostratigraphique et paléoécologique des ostracodes du récif de marbre rouge du Hautmont à Vodelée (partie supérieure du Frasnien, Bassin de Dinant, Belgique). Revue de Paléobiologie 6: 193-204.

Carls, P., Slavik, L., and Valenzuela-Ríos, J. 2007. Revisions of conodont biostratigraphy across the Silurian-Devonian boundary. Bulletin of Geosciences 82: 145-164.

Clarke, J.M. 1899. A fauna siluriana superior do Rio Trombetas, Es- 
tado do Pará, Brazil. Archivos do Museo Nacional do Rio de Janeiro 10: 1-48.

Copeland, M.J. 1962. Canadian fossil Ostracoda, Conchostraca, and Phyllocarida. Canada. Geological Survey Bulletin 91: 1-57.

Copeland, M.J. 1977. Early Palaeozoic Ostracoda from Southwestern district of Mackenzie and Yukon Territory. Bulletin of the Geological Survey of Canada 275: 1-88.

Corradini, C., and Corriga, M.G. 2017. Conodonts across the Silurian/ Devonian boundary in the Carnic Alps (Italy-Austria). Publicaciones del Instituto Geológico y Minero de España, Serie: Cuadernos del Museo Geominero 22: 115-118.

Corriga, M.G., Corradini, C., Schönlaub, H.P., and Pondrelli, M. 2016. Lower Lochkovian (Lower Devonian) conodonts from Cellon section (Carnic Alps, Austria). Bulletin of Geosciences 91: 261270.

Dojen, C. 2005. [Early Devonian ostracods of Celtiberia (NE Spain)taxonomy, palaeoecology, biostratigraphy, and biogeography. Braunschweig, Technische Universität, Dissertation 19, 256 p. Electronic edition. http://opus.tu-bs.de/opus/volltexte/ 2005/ 815. Unpublished.].

Dojen, C., Gozalo, R., Carls, P., and Valenzuela-Ríos, J.I. 2004. Early and Late Devonian ostracod faunas from the Iberian Chains. Revista Española de Micropaleontología 36: 171-185.

Dojen, C., Valenzuela-Ríos, J.I., and Carls, P. 2007. Lochkovian to Pragian (Lower Devonian) neritic Ostracodes from Nigüella (Zaragoza, Iberian Chains, NE Spain). Revista Española de Paleontología 22: 105-113.

Drygant, D., and Szaniawski, H. 2012. Lochkovian conodonts from Podolia, Ukraine and their stratigraphic significance. Acta Palaeontologica Polonica 57: 833-861.

Franciosi, M. 1995. [Estratigrafía, paleontología y correlación de las unidades silúricas del Río San Juan, Precordillera Argentina. Trabajo final de Grado, Facultad de Ciencias Exactas, Físicas y Naturales, Universidad Nacional de Córdoba, Córdoba, 113 p. Unpublished.].

Garcías, Y.V. 2016. [Estratigrafía y Bioestratigrafía de conodontes de la Formación Los Espejos (Silúrico) en Quebrada Poblete, Talacasto, Precordillera Central. Tesis de Licenciatura, Facultad de Ciencias Exactas Físicas y Naturales, Universidad Nacional de San Juan, San Juan, 66 p. Unpublished.].

Gómez, M.J. 2015. [Estratigrafía y bioestratigrafía de conodontes de la Formación Los Espejos (Silúrico) en Quebrada Ancha, Talacasto, Precordillera Central. Tesis de Licenciatura, Facultad de Ciencias Exactas Físicas y Naturales, Universidad Nacional de San Juan, San Juan, 86 p. Unpublished.].

Gómez, M.J., Garcías, Y., Corradini, C., Mestre, A., and Heredia, S. 2017. El horizonte de "Ozarkodina" eosteinhornensis s.s. (Pridoliano) en la Formación Los Espejos, Talacasto, Precordillera Central, San juan, Argentina. $20^{\circ}$ Congreso Geológico Argentino (Tucumán), Actas Simposio 11: 32-37.

Gründel, J. 1966. Zur Entwicklung und Taxionomie der Tricornidae (Ostracoda) in Mitteleuropa. Paläontologische Zeitschrift 40: 89-102.

Hansch, W. 1993. Stratigraphical, palaeoecological and palaeobiogeographical aspects of the Upper Silurian ostracod faunas of Baltoscandia and Central Europe. $17^{\text {th }}$ International Symposium of Ostracoda (Warrnambool), Proceedings: 23-37.

Hansch, W. 1994. Beyrichiacean ostracode moulds from the Kirusillas Formation (Silurian) of Central Bolivia. Neues Jahrbuch für Geologie und Paläontologie Monatshefte 2: 75-81.

Heim, A. 1952. Estudios tectónicos en la Precordillera de San Juan. Los ríos San Juan, Jáchal y Huaco. Revista de la Asociación Geológica Argentina 7: 11-70.
Henningsmoen, G. 1953. Classification of Paleozoic straight-hinge ostracods. Norske Geologische Tidsskrift 31: 185-288.

Huškova, A., and Slavík, L. 2017. Conodonts of Family Spathognathodontidae from the Silurian/Devonian boundary, Prague Synform. Publicaciones del Instituto Geológico y Minero de España, Serie: Cuadernos del Museo Geominero 22: 113-114.

Jones, T. 1890. On some Devonian and Silurian Ostracoda from North America, France, and the Bosphorus. Quarterly Journal of the Geological Society of London 46: 534-556.

Jones, T.R., and Holl, H.B. 1869. Notes on the Paleozoic Entomostraca. 9. Some Silurian species. Annals and Magazine of Natural History 4: 211-229.

Jones, T.R., and Holl, H.B. 1886. Notes on the Palaeozoic bivalve Entomostraca 20: on the genus Beyrichia and some new species. The Annals and Magazine of Natural History 5: 337-363.

Krandijevsky, V.S. 1968. Revision of the family Thlipsuridae Ulrich (Ostracoda). In: V.S. Krandijevsky, T.A. Ishchenko, and V.V. Kiryanov (Eds.), Paleontology and Stratigraphy of the Lower Paleozoic of Volyn-Podolia. Academy Nauk Ukranian SSR, Kiev, p. 63-71. [In Russian].

Lundin, R.F. 1968. Ostracodes of the Haragan Formation (Devonian) in Oklahoma. Oklahoma Geological Survey, Bulletin 116: 1-121.

Lundin, R.F., and Petersen, L.E. 1975. Thlipsura Jones and Holl: a redescription of the type species. In: F.M. Swain (Ed.), Biology and Paleobiology of Ostracoda. Paleontological Research Institution, Ithaca, New York, p. 87-107.

Martinsson, A. 1962. Ostracodes of the family Beyrichiidae from the Silurian of Gotland. Geological Institution of the University of Uppsala Bulletin 41: 1-369.

Martinsson, A. 1964. Hemsiella andincola, a new beyrichiacean ostracode from the Silurian of Venezuela. Geolologiska Föreningens Stockholm Förhandling 86: 238-247.

Meidla, T. 1996. Late Ordovician ostracodes of Estonia. Fossilia Baltica 2: 1-224.

Meidla, T. 2007. Ostracods from the Upper Ordovician Borenshult fauna, Sweden. Journal of the Geological Society of Sweden 129: $123-132$.

Mestre, A. 2009. Primeros conodontes de la Formación Tambolar (Facies Pachaco), Silúrico de la Precordillera Argentina, y sus implicancias bioestratigráficas. Ameghiniana 46: 469-479.

Mestre, A., Gómez, M.J., Garcías, Y., Corradini, C., and Heredia, S. 2017. Advances on Silurian-Devonian conodont biostratigraphy in the Central Precordillera, Argentina. Publicaciones del Instituto Geológico y Minero de España, Serie: Cuadernos del Museo Geominero 22: 105-108.

Mohibullah, M., Williams, M., and Zalasiewicz, J. 2014. Late Ordovician ostracods of the Girvan district, south-west Scotland. Monograph of the Palaeontographical Society London 640 (part of Vol. 167): 1-40.

Moore, R.C. 1961. Morphological Terms. In: R.C. Moore, and C.W. Pitrat (Eds.), Treatise on Invertebrate Paleontology, Part Q Arthropoda 3 Crustacea Ostracoda. Geological Society of America, Boulder and University of Kansas Press, Lawrence, p. Q99-Q421.

Müller, G.W. 1894. Die Ostrakoden des Golfes von Neapel und der angrenzenden Meeres-Abschnitte. Herausgegeben von der zoologischen Station zu Neapel 21: 1-404.

Murphy, M.A., Valenzuela-Ríos, J.L., and Carls, P. 2004. On classification of Pridoli (Silurian)-Lochkovian (Devonian) Spathognathodontidae (Conodonts). University of California, Riverside Campus Museum Contribution 6: 1-25.

Peralta, S., and León, L. 1993. Estratigrafía, sedimentología y correlación de los depósitos silúricos de Pachaco, Precordillera Central sanjuanina. $12^{\circ}$ Congreso Geológico Argentino y $2^{\circ}$ Con- 
greso de Exploración de Hidrocarburos (Mendoza), Actas 1: 142147.

Pinto, A., and Purper, G. 1981. New lower Palaeozoic ostracods from Bolivia. $2^{\circ}$ Congresso Latino-Americano de Paleontología (Porto Alegre), Actas: 45-59.

Pokorny, V. 1954. A contribution to the taxonomy of the Paleozoic ostracods. Sbornik ústředniho ústavu geologickeho (oddil paleontologicky) 20 (for 1953): 213-232.

Pribyl, A. 1984. Ostracodes from the Ordovician and Silurian of Bolivia. Časopis Pro Mineralogii a Geologii 29: 353-368.

Roth, R.I. 1929. Some ostracodcs from the Haragan Marl, Devonian, of Oklahoma. Journal of Paleontology 3: 327-372.

Salas, M.J. 2002a. Ostrácodos binodicopas del Ordovícico de la Precordillera de San Juan, Argentina. Ameghiniana 39: 41-58.

Salas, M.J. 2002b. Ostrácodos podocopas del Ordovícico de la Precordillera de San Juan, Argentina. Ameghiniana 39: 129-139.

Salas, M.J. 2003. Ostrácodos palaeocopas, leiocopas y eridostracas del Ordovícico de la Precordillera de San Juan, Argentina. Ameghiniana 40: 345-360.

Salas, M.J. 2007. Assessing the biodiversity of Ordovician ostracods from the Argentine Precordillera. Journal of Paleontology 81: $1442-1453$

Salas, M.J. 2011. Early Ordovician (Floian) ostracods from the Cordillera Oriental, Northwest Argentina. Geological Journal 46: 637-650.

Salas, M.J. 2016. New insights on earliest Devonian (Lochkovian) ostracods from the Argentine Precordillera. Ameghiniana 53: 565-585.

Salas, M.J., and Vaccari, N.E. 2012. New insights into the early diversification of the Ostracoda: Tremadocian ostracods from the Cordillera Oriental, Argentina. Acta Palaeontologica Polonica 57: 175-190.

Salas, M.J., Vannier, V., and Williams, M. 2007. Early Ordovician ostracods from Argentina: their bearing on the origin of binodicope and palaeocope clades. Journal of Paleontology 81: $1384-1395$

Salas, M.J., Rustán, J.J., and Sterren, A.F. 2013. Lower and Middle Devonian Malvinokaffric ostracods from the Precordillera Basin of San Juan, Argentina. Journal of South American Earth Sciences 45: $56-68$

Schallreuter, R.E.L. 1990. Ordovizische Ostrakoden und Seeigel der Karnischen Alpen und ihre Beziehungen zu Böhmen und Baltoskandien. Neues Jahrbuch für Geologie und Paläontologie Monatshefte 2: 120-128.

Schallreuter, R.E.L. 1996. Ordovizische Ostracoden Argentiniens II. Mitteilungen aus dem Geologisch-Paläontologischen Institut der Universität Hamburg 79: 139-169.

Serpagli, E. 1974. Lower Ordovician conodonts from Precordillera Argentina (Province of San Juan). Bolletino della Societá Paleontologica Italiana 13: 17-98.

Siveter, D.J. 1980. British Silurian Beyrichiacea (Ostracoda), Part 1. Palaeontographical Society Monographs: 1-76.

Siveter, D.J. 1989. Ostracodes. In: C.H. Holland, and M.G. Bassett (Eds.), A Global Standard for the Silurian System. Geological Series 9. National Museum of Wales, Cardiff, p. 252-264.

Siveter, D.J. 2009. The Silurian. In: J.E.W. Whittaker, and M.B. Hart (Eds.), Ostracods in British Stratigraphy. The Micropalaeontological Society, Special publications. Geological Society London, London, p. 45-90.
Slavík, L., Carls, P., Hladil, J., and Koptíková, L. 2012. Subdivision of the Lochkovian Stage based on conodont faunas from the stratotype area (Prague Synform, Czech Republic). Geological Journal 47: 616-631.

Stone, J. 1987. Review of investigative techniques used in the study of conodonts. In: R. Austin (Ed.), Conodonts: Investigative Techniques and Applications. Ellis Horwood Limited, Chichester, p. $17-34$.

Stone, S.M., and Berdan, J.M. 1984. Some Late Silurian (Pridolian) ostracodes from the Roberts Mountains, Central Nevada. Journal of Paleontology 58: 977-1009.

Swartz, F.M. 1932. Revision of the ostracode family Thipsuridae, with descriptions of new species from the Lower Devonian of Pennsylvania. Journal of Paleontology 6: 36-58.

Swartz, F.M., and Swain, F.M. 1941. Ostracods of the Middle Devonian Onondaga beds of central Pennsylvania. Geological Society of America Bulletin 52: 381-457.

Thomas, I. 1905. Neue Beiträge zur Kenntnis der devonischen Fauna Argentiniens. Zeitschrift der Deutschen geologischen Gesellschaft 57: 233-290.

Troedsson, G.T. 1918. Om Skanes brachiopodskiffer. Lunds Universitat Ârsskrift, Nv Följd 15: 1-110.

Ulrich, E.O. 1894. The Lower Silurian Ostracoda of Minnesota. Report of the Geological and Natural History Survey of Minnessota 3: 629-693.

Ulrich, E.O., and Bassler, R.S. 1913. Ostracoda. In: C.K. Swartz (Ed.), Systematic paleontology of the lower Devonian deposits of Maryland. Maryland Geological Survey, Lower Devonian volume. The Johns Hopkins Press, Baltimore, p. 513-542.

Ulrich, E.O., and Bassler, R.S. 1923. Paleozoic Ostracoda: Their Morphology, Classification and Ocurrence. In: C.K. Swartz (Ed.), Silurian. The Johns Hopkins Press, Baltimore, p. 271-391.

Vannier, J.M.C., Siveter, D., and Schallreuter, R.E.L. 1989. The composition and palaeogeographical significance of the Ordovician ostracode faunas of Southern Britain, Baltoscandia and IberoArmorica. Palaeontology 32: 163-222.

Vannier, J.M.C., Racheboeuf, P.R., and Benedetto, J.L. 1995. Silurian early Devonian ostracods from South America (Argentina, Bolivia): preliminary investigations. Journal of Paleontology 69: $752-772$

Walliser, O.H. 1964. Conodonten des Silurs. Abhandlungen des Hessischen Landesamtes für Bodenforschung 41: 1-106.

Zagora, K. 1968. Ostracoden aus dem Grenzbereich Unter- Mitteldevon von Ostthüringen. Geologie 17: 1-91.

doi: 10.5710/AMGH.23.04.2018.3140

Submitted: July 21 1 st 2017

Accepted: April 23th 2018

Published online: April 25 $5^{\text {th }}, 2018$ 